\title{
Treatment of Drug-Resistant Tuberculosis: Current Status
}

\author{
Rajendra Prasad ${ }^{1,2}$ Harsh Saxena ${ }^{1} \quad$ Nikhil Gupta $^{3} \quad$ Mohammad Tanzeem $^{1} \quad$ Ronal Naorem ${ }^{1}$ \\ 1Department of Pulmonary Medicine, Era's Lucknow Medical \\ College and Hospital, Lucknow, Uttar Pradesh, India \\ 2Former Director, Vallabhbhai Patel Chest Institute, New Delhi, India \\ ${ }^{3}$ Department of General Medicine, Dr. Ram Manohar Lohia Institute \\ of Medical Sciences, Lucknow, Uttar Pradesh, India \begin{abstract}
A-28, Sector J, Aliganj, Lucknow 226024, Uttar Pradesh, India (e-mail: rprasadkgmc@gmail.com).
\end{abstract} \\ Address for correspondence Rajendra Prasad, MD, DTCD, MBBS, \\ Ann Natl Acad Med Sci (India) 2021;57:68-73.
}

\begin{abstract}
Drug-resistant tuberculosis (DR-TB) has been an area of growing concern and posing threat to human health worldwide. The treatment has been defined for all types of DR-TB with or without newer anti-TB drugs. multi-DR-TB (MDR-TB) patients have now choice of two types of regimen, shorter and longer regimens. Shorter regimen for treatment of subset of MDR-TB patients who have not been previously treated with second line drugs and in whom resistance to fluoroquinolones and second-line injectable agents has been excluded is given for 9 to 11 months. A longer regimen of at least five effective anti-TB drugs (ATDs) during the intensive phase is recommended, including pyrazinamide and four core second-line ATDs. Intensive phase, including injectables, should be given for at least 8 months. The total duration of treatment is at least 20 months, which can be prolonged up to 24 months depending on the response of the patient. World Health Organization (WHO) has recently revised the grouping of ATD for use in DR-TB patients in 2018 into three groups based on individual patient data meta-analysis depending on their individual efficacy, risk of relapse, treatment failure, and death. Recently, an all oral longer regimen comprising bedaquiline, pretomanid, and linezolid (BPal regime) for 6 to 9 months for extensive-DR-TB (XDR-TB) patients and those MDR-TB patients

Keywords

- drug-resistant tuberculosis

- shorter regimen

- longer regimen who cannot tolerate or do not respond to conventional MDR-TB regimen. These new developments will be a step forward toward establishing universal regimen to treat all types of DR-TB. This article has summarized the current evidence from literature search to date, including prevalence of DR-TB, types of regimen used and the advancement in the regimens for effective treatment of DR-TB patients.
\end{abstract}

\section{Introduction}

Tuberculosis (TB) occurs worldwide and remains an important cause of morbidity and mortality in many countries. Ideally good treatment of TB should achieve sputum conversion in almost all the patients provided correct regimens are prescribed and taken. There will be hardly any recurrence if duration of treatment has been adequate and there will be hardly any emergence of drug resistance. ${ }^{1}$ The Global Tuberculosis Report 2019 estimated that 3.4\% of newly

published online July 21, 2020
DOI https://doi.org/ $10.1055 / \mathrm{s}-0040-1714201$ ISSN 0379-038X. diagnosed and $18 \%$ of previously treated TB cases had multidrug-resistant TB (MDR-TB). It has been estimated that 484,000 cases of rifampicin-resistant TB (RR-TB) and 78\% out of them had MDR-TB causing death to 214,000 people globally in 2018. Out of 484,000 cases who developed MDR/RR-TB, $186,772(39 \%)$ cases were detected and 156,071 people $(32 \%)$ were enrolled on treatment with a second-line regimen and only $56 \%$ of them were treated successfully in 2018 . In India, it is estimated that the prevalence of MDR-TB among new and previously treated patients was 2.8 and $14 \%$, respectively. It

(C) 2020. National Academy of Medical Sciences (India).

This is an open access article published by Thieme under the terms of the Creative Commons Attribution-NonDerivative-NonCommercial-License, permitting copying and reproduction so long as the original work is given appropriate credit. Contents may not be used for commercial purposes, or adapted, remixed, transformed or built upon. (https://creativecommons.org/licenses/by-nc-nd/4.0/).

Thieme Medical and Scientific Publishers Pvt. Ltd. A-12, 2nd Floor, Sector 2, Noida-201301 UP, India 
is estimated that 130,000 cases of MDR/RR-TB emerge every year of which 58,347 (44.9\%) were detected and notified and 46,569 (35.8\%) were started on treatment with treatment success rate of only $48 \%{ }^{2}$ Extensive drug-resistant TB (XDR-TB) has been reported in all regions of the world and it has become a serious emerging threat to global public health. But, 6.2\% of MDR-TB cases were found to have XDR-TB. It is estimated that 30,000 cases of XDR-TB emerge every year globally. Out of 30,000 XDR TB cases only 13,068 (43\%) were diagnosed and $11,403(38 \%)$ were started on treatment with treatment success rate of 39\% globally. In India, out of estimated 8,000 cases of XDR-TB, only 3,400 (42\%) cases were detected and notified and 2,724 (34\%) were put on treatment with success rate of $30 \%$. Recently, there have been many newer changes in treatment of DR-TB. Present write up aims to review current status of treatment of various forms of DR-TB.

\section{Drug-Resistant Tuberculosis}

There are many types of DR-TB. Isoniazid-resistant TB (Hr-TB), refers to TB cases whose Mycobacterium tuberculosis strains are resistant to isoniazid and susceptibility to rifampicin has been confirmed by drug-susceptibility testing (DST). Polyresistance TB refers to TB cases who are resistant to more than one first-line anti-TB drug, other than isoniazid and rifampicin together. RR-TB defined as resistance to rifampicin detected using genotypic or phenotypic methods with or without resistance to other first line anti-TB drugs. Rifampicin resistance is taken as surrogate marker for MDR-TB. MDR-TB refers to TB cases whose sputum is culture positive for M. tuberculosis and is resistant in vitro to isoniazid and rifampicin with or without other antitubercular drugs based on DST. Pre-XDR-TB) refers to TB cases who are resistant to one of the fluoroquinolone (ofloxacin, levofloxacin, and moxifloxacin) or a second-line injectable anti-TB drug (kanamycin, amikacin, and capreomycin), confirmed by DST. XDR-TB refers to MDR-TB case whose recovered M. tuberculosis isolate is resistant to any fluoroquinolone (ofloxacin, levofloxacin, and moxifloxacin) and a second-line injectable anti-TB drug (kanamycin, amikacin, and capreomycin), confirmed by DST.

\section{Treatment of Isoniazid-Resistant Tuberculosis}

Isoniazid is an important first-line agent for the treatment of $\mathrm{TB}$, possessing potent early bactericidal activity against M. tuberculosis. Monoresistance to isoniazid is frequent worldwide with an estimated prevalence of $7.2 \%$ in new TB cases and $11.6 \%$ in previously treated TB cases. ${ }^{2}$ In patients with confirmed rifampicin-susceptible and $\mathrm{Hr}-\mathrm{TB}$, treatment with rifampicin, ethambutol, pyrazinamide, and levofloxacin is recommended for duration of 6 months. In patients with confirmed rifampicin-susceptible and $\mathrm{Hr}-\mathrm{TB}$, it is not recommended to add streptomycin or other injectable agents to the treatment regimen. If second line probe assay shows levofloxacin resistance, then it should be replaced with high-dose moxifloxacin. If high-dose moxifloxacin or pyrazinamide cannot be used then it should be replaced with linezolid. If linezolid cannot be given, then it should be replaced with clofazimine. If both linezolid and clofazimine cannot be given, then add cycloserine. If both high-dose moxifloxacin and pyrazinamide cannot be used, then two drugs out of the three, that is, linezolid, clofazimine, and cycloserine should be added in order of preference. In all the above situations, regimen should be extended for a period of 9 months instead of 6 months duration. ${ }^{3}$ In patients in whom toxicity from pyrazinamide is either experienced or anticipated, or in patients with lower burden of disease (i.e., noncavitary), shortening of the duration of pyrazinamide can be done when a later-generation fluoroquinolone is included in the regimen. Further research evaluating the efficacy, safety, and tolerability of shorter versus longer durations of pyrazinamide are urgently required. ${ }^{4}$

\section{Treatment of Multidrug-Resistant/ Rifampicin-Resistant-Tuberculosis}

For treatment of MDR/RR-TB, standardized, empirical, and individualized approaches have been laid down., ${ }^{5,6}$ Individualized treatment based on individual DST and prior treatment history is costly and needs skilled professionals and quality assured bacteriological and molecular diagnostic laboratories whereas, standardized treatment is simple, less costly and same treatment is given to all patients. There are two types of treatment regimen MDR/RR-TB shorter and longer regimen according to recent update from World Health Organization (WHO) in which they have also reclassified anti-TB drugs (ATD) for MDR/RR-TB ${ }^{7}$ (-Table 1 ).

\section{Shorter Regimen for Multidrug-Resistant/Rifampicin- Resistant Tuberculosis}

In 2016, WHO approved the use of a shorter regimen for treatment for subset of MDR/RR-TB patients who have not been previously treated with second-line drugs and in whom resistance to fluoroquinolones and second-line injectable agents has been excluded or is considered highly unlikely, a shorter MDR/RR-TB regimen of 9 to 11 months may be used instead of a longer regimen of 20 to 24 months. The intensive phase of 4 months which may be extended to 6 months in case of lack of sputum smear conversion consists of kanamycin, High dose moxifloxacin, ethionamide, clofazimine, pyrazinamide, High-dose isoniazid, ethambutol, followed by continuation phase of 5 months which consist of high-dose moxifloxacin, clofazimine, pyrazinamide, and ethambutol. ${ }^{7-9}$ Recommendation for use of shorter regimen was conditional and it can be used in selected patients with MDR/RR-TB with the exception of confirmed resistance or suspected ineffectiveness to any medicine in the shorter regimen (except isoniazid), exposure to one or more second-line medicines in the shorter regimen for 1 or more months unless susceptibility to these second-line medicines is confirmed, intolerance to one or more medicines in the shorter regimen or at increased risk of toxicity from such medication (e.g., drug-drug interactions, preexisting QT-interval prolongation), pregnancy, extra pulmonary disease in people living with human immunodeficiency virus and disseminated, meningeal or central 
Table 1 Grouping of anti-tuberculosis drugs with their doses used in drug resistant tuberculosis (WHO 2016)

\begin{tabular}{|c|c|c|c|c|c|}
\hline \multirow{2}{*}{\multicolumn{2}{|c|}{ Groups }} & \multirow[t]{2}{*}{ Drugs } & \multirow{2}{*}{$\begin{array}{l}\text { Average daily } \\
\text { dose }(\mathrm{mg} / \mathrm{kg})\end{array}$} & \multicolumn{2}{|c|}{ Daily dosage (mg) } \\
\hline & & & & Minimum & Maximum \\
\hline \multirow{3}{*}{\multicolumn{2}{|c|}{ A. Fluoroquinolones }} & Levofloxacin & $7.5-10$ & 750 & 1000 \\
\hline & & Moxifloxacin & $7.5-10$ & 400 & 400 \\
\hline & & Gatifloxacin & $7.5-10$ & 400 & 400 \\
\hline \multirow{4}{*}{\multicolumn{2}{|c|}{$\begin{array}{l}\text { B. Second-line } \\
\text { injectable agents }\end{array}$}} & Amikacin & 15 & 500 & 1000 \\
\hline & & Kanamycin & 15 & 500 & 1000 \\
\hline & & Capreomycin & 15 & 500 & 1000 \\
\hline & & Streptomycin & 15 & 500 & 1000 \\
\hline \multirow{4}{*}{\multicolumn{2}{|c|}{$\begin{array}{l}\text { C. Other core } \\
\text { second-line agent }\end{array}$}} & Ethionamide/prothionamide & $15-20$ & 500 & 1000 \\
\hline & & Cycloserine/terizidone & $10-20$ & 500 & 1000 \\
\hline & & Linezolid & - & 600 & 600 \\
\hline & & Clofazimine & $4-5$ & 100 & 300 \\
\hline \multirow{10}{*}{$\begin{array}{l}\text { D. Add-on } \\
\text { agents }\end{array}$} & D1 & Pyrazinamide & 25 & 750 & 2000 \\
\hline & & Ethambutol & 15 & 600 & 1200 \\
\hline & & High-dose isoniazid & $16-20$ & 600 & 1500 \\
\hline & $\mathrm{D} 2$ & Bedaquiline & \multicolumn{3}{|c|}{$\begin{array}{l}400 \mathrm{mg} \text { OD } \times 2 \text { weeks and then } 200 \mathrm{mg} \text { three } \\
\text { times per week }\end{array}$} \\
\hline & & Delamanid & \multicolumn{3}{|l|}{$100 \mathrm{mg} \mathrm{BD}$} \\
\hline & D3 & PAS & $200-300$ & $10 \mathrm{gm}$ & $12 \mathrm{gm}$ \\
\hline & & Imipenem-cilastatin & \multicolumn{3}{|c|}{ 1,000-1,000 mg BD } \\
\hline & & Meropenem & \multicolumn{3}{|c|}{$1,000 \mathrm{mg}$ thrice daily } \\
\hline & & Amoxicillin-clavulanate & $80 \mathrm{mg} / \mathrm{kg} /$ day & $\begin{array}{l}500 / 125 \mathrm{mg} \\
\mathrm{BD}\end{array}$ & $1,000 / 250 \mathrm{mg} \mathrm{BD}$ \\
\hline & & Thioacetazone & \multicolumn{3}{|l|}{$150 \mathrm{mg}$ OD } \\
\hline
\end{tabular}

Abbreviations: BD, twice daily; OD, once daily; WHO, World Health Organization.

Table 2 Drugs and doses used in shorter MDR regimen for patients older than 14 years from the WHO MDR-TB treatment 2018

\begin{tabular}{|l|l|l|l|l|l|l|}
\hline Medicine & $\begin{array}{l}\text { Weight based daily } \\
\text { dose }(\mathrm{mg} / \mathrm{kg})\end{array}$ & \multicolumn{5}{|c|}{ Weight bands for patients older than 14 years } \\
\hline Weight groups $(\mathrm{kg})$ & & $\mathbf{3 0 - 3 5}$ & $\mathbf{3 6 - 4 5}$ & $\mathbf{4 6 - 5 5}$ & $\mathbf{5 6 - 7 0}$ & $>70$ \\
\hline Moxifloxacin & (High dose) $10-15$ & $400 / 600$ & 600 & $600 / 800$ & 800 & 800 \\
\hline Clofazimine & 1 & 100 & 100 & 100 & 100 & 100 \\
\hline Ethambutol & $15-25$ & 800 & 800 & 1,200 & 1,200 & 1,200 \\
\hline Pyrazinamide & $20-30$ & 1,000 & 1,500 & 1,500 & 1,500 & 2,000 \\
\hline Amikacin & $15-20$ & 500 & 500 & 750 & 750 & 1,000 \\
\hline $\begin{array}{l}\text { Ethionamide or } \\
\text { prothionamide }\end{array}$ & $15-20$ & 500 & 500 & 750 & 750 & 1,000 \\
\hline Isoniazid & (High dose) $15-20$ & $600 / 1,000$ & $1,000 / 1,500$ & 1,500 & 1,500 & 1,500 \\
\hline
\end{tabular}

Abbreviations: MDR, multidrug resistant; TB, tuberculosis; WHO, World Health Organization.

nervous system TB. WHO updated guidelines for MDR/RR-TB in 2018 and 201910,11 continued to include the shorter regimen as an option for patients who have not been previously treated for more than 1 month with second-line medicines used in the shorter MDR-TB regimen or in whom resistance to fluoroquinolones and second-line injectable agents has been excluded and now the shorter MDR-TB regimen may be offered under certain criteria which were similar to the previous guidelines except that shared decision making between the clinician and patient is important when choosing between a shorter and longer regimen and kanamycin should be replaced by amikacin. Doses of drugs used in shorter regimen has been revised in recently for patients older than 14 years (-Table 2).

Abidi et al reported results of individual patient data meta-analysis comparing the standardized shorter regimen 
with individualized longer regimen. They reported that treatment success rate was higher with the shorter regimen than with individualized longer regimen due to less loss to follow-up. The failure and relapse was slightly higher with shorter regimen and was greater in magnitude with baseline resistance to pyrazinamide, ethionamide/prothionamide or ethambutol. These finding also support the need to improve access to reliable drug susceptibility test. ${ }^{12}$ STREAM has recently expanded (stage 2) to test two additional shorter treatment regimens using bedaquiline. ${ }^{13}$ This expanded arm will evaluate a 9-month all-oral regimen without injections and an even shorter simplified 6-month regimen. It will finish enrollment of patients in 2018 and initial results are expected by 2021.

\section{Longer Regimen for Multidrug-Resistant/Rifampicin- Resistant Tuberculosis}

In patients with MDR/RR-TB, a longer regimen of least five effective ATDs during the intensive phase is recommended, including pyrazinamide and four core second-line ATDs, one chosen from group A (fluoroquinolones: levofloxacin, moxifloxacin, and gatifloxacin), one from group B (second-line injectable drugs: kanamycin, amikacin, and capreomycin), and at least two from group C (other core second-line drugs: ethionamide/ prothionamide, cycloserine/terizidone, linezolid, and clofazimine). If the minimum of effective ATDs cannot be composed as above, one drug from group D2 (bedaquiline and delamanid) and other drugs from D3 (para-aminosalicylic acid,imipenem-cilastatin, meropenem, amoxicillin-clavulanate, and thioacetazone) may be added to bring the total number of drugs to five. The regimen may be further strengthened with rest of group D1 (high-dose isoniazid and/or ethambutol). While streptomycin is not usually included with the second-line drugs, it can be used as the injectable drug of the core MDR/RR-TB regimen if none of the three other injectable drugs can be used and if the strain can be reliably shown not to be resistant. Thioacetazone should not be used if the patient is HIV seropositive. Intensive phase including injectables should be given for at least 8 months for most patients which can be modified depending on the response of the patient. The total duration of treatment is at least 20 months which can be prolonged up to 24 months depending upon the response of the patient. Pyrazinamide is usually continued for the entire treatment, especially if there is extensive disease. If the patient has minimal disease, pyrazinamide can be stopped with injectables at end of intensive phase. Bedaquiline or delamanid are used for 6 months in intensive phase and are presently not recommended for whole treatment duration., ${ }^{74,15}$ It is important that a single drug should never be added to a failing regimen and it is ineffective to combine two drugs of the same group or to add a drug potentially ineffective because of cross resistance. No drug should be kept in reserve and the most powerful drugs should be used initially and in maximum combination so as to ensure that first battle is won and won permanently. All patients initiated on treatment and their family members should be intensively counseled prior to treatment initiation and during all follow-up visits. To reduce the risk of development of resistance to second-line
Table 3 Regimen for MDR/RR-TB, pre-XDR- and XDR-TB with and without new drugs

\begin{tabular}{|c|c|c|}
\hline Type of regimen & $\begin{array}{l}\text { Treatment regimen in } \\
\text { intensive phase }\end{array}$ & $\begin{array}{l}\text { Treatment } \\
\text { regimen in } \\
\text { continuation } \\
\text { phase }\end{array}$ \\
\hline $\begin{array}{l}\text { Conventional } \\
\text { regimen for MDR/ } \\
\text { RR-TB }\end{array}$ & $\begin{array}{l}\text { (6-9 months) kanamycin, } \\
\text { levofloxacin ethionamide, } \\
\text { cycloserine, pyrazinamide, } \\
\text { ethambutol }\end{array}$ & $\begin{array}{l}\text { (18 months) } \\
\text { levofloxacin, } \\
\text { ethionamide, } \\
\text { cycloserine, } \\
\text { ethambutol }\end{array}$ \\
\hline $\begin{array}{l}\text { Regimen for MDR/ } \\
\text { RR-TB + resistance } \\
\text { to FQ class (with- } \\
\text { out new drugs) }\end{array}$ & $\begin{array}{l}\text { (6-9 months) kanamycin, } \\
\text { high dose moxifloxacin, } \\
\text { ethionamide, cycloserine, } \\
\text { pyrazinamide, linezolid, } \\
\text { clofazimine }\end{array}$ & $\begin{array}{l}\text { (18 months) } \\
\text { high dose } \\
\text { moxifloxacin, } \\
\text { ethionamide, } \\
\text { cycloserine, } \\
\text { pyrazinamide, } \\
\text { linezolid, } \\
\text { clofazimine }\end{array}$ \\
\hline $\begin{array}{l}\text { Regimen for MDR/ } \\
\text { RR-TB + resistance } \\
\text { to SLI class (with- } \\
\text { out new drugs) }\end{array}$ & $\begin{array}{l}\text { (6-9 months) capre- } \\
\text { omycin, levofloxacin, } \\
\text { ethionamide, cycloserine, } \\
\text { pyrazinamide, linezolid, } \\
\text { clofazimine }\end{array}$ & $\begin{array}{l}\text { (18 months) } \\
\text { levofloxacin, } \\
\text { ethionamide, } \\
\text { cycloserine, } \\
\text { linezolid }\end{array}$ \\
\hline $\begin{array}{l}\text { Regimen for MDR/ } \\
\text { RR-TB + resistance } \\
\text { to FQ class (with } \\
\text { new drugs) }\end{array}$ & $\begin{array}{l}\text { (6-9 months) kanamycin, } \\
\text { ethionamide, cycloserine, } \\
\text { pyrazinamide, linezolid, } \\
\text { clofazimine + ( } 6 \text { months) } \\
\text { bedaquiline }\end{array}$ & $\begin{array}{l}\text { (18 months) } \\
\text { ethionamide, } \\
\text { cycloserine, } \\
\text { linezolid, } \\
\text { clofazimine }\end{array}$ \\
\hline $\begin{array}{l}\text { Regimen for MDR/ } \\
\text { RR + resistance to } \\
\text { SLI class (with new } \\
\text { drug) }\end{array}$ & $\begin{array}{l}\text { (6-9 months) } \\
\text { capreomycin,levofloxacin, } \\
\text { ethionamide, cycloserine, } \\
\text { pyrazinamide, linezolid, } \\
\text { clofazimine + (6 months) } \\
\text { bedaquiline }\end{array}$ & $\begin{array}{l}\text { (18 months) } \\
\text { levofloxacin, } \\
\text { ethionamide, } \\
\text { cycloserine, } \\
\text { linezolid }\end{array}$ \\
\hline $\begin{array}{l}\text { Regimen for } \\
\text { XDR-TB (without } \\
\text { new drugs) }\end{array}$ & $\begin{array}{l}\text { (6-12 months) } \\
\text { capreomycin, high } \\
\text { dose moxifloxacin, } \\
\text { ethionamide, cycloserine, } \\
\text { pyrazinamide, linezolid, } \\
\text { clofazimine, ethambutol }\end{array}$ & $\begin{array}{l}\text { (18 months) } \\
\text { high dose } \\
\text { moxifloxacin, } \\
\text { ethionamide, } \\
\text { cycloserine, } \\
\text { linezolid, } \\
\text { clofazimine, } \\
\text { ethambutol }\end{array}$ \\
\hline $\begin{array}{l}\text { Regimen for } \\
\text { XDR-TB (with new } \\
\text { drugs) }\end{array}$ & $\begin{array}{l}\text { (6-12 months) } \\
\text { capreomycin, } \\
\text { ethionamide, cycloserine, } \\
\text { pyrazinamide, } \\
\text { linezolid, clofazimine, } \\
\text { ethambuto, + (6 months) } \\
\text { bedaquiline }\end{array}$ & $\begin{array}{l}\text { (18 months) } \\
\text { ethionamide, } \\
\text { cycloserine, } \\
\text { linezolid } \\
\text { clofazimine, } \\
\text { ethambutol }\end{array}$ \\
\hline
\end{tabular}

Abbreviations: Fl, fluoroquinolones; MDR, multidrug resistant; $\mathrm{RR}$, rifampicin resistant; TB, tuberculosis; SLI, second line injectables; $\mathrm{XDR}$, extensive drug resistant.

ATDs and promote optimal treatment outcomes, all efforts should be made to administer treatment under direct observation (DOT) over the entire course of treatment. If DOT is not possible, attempts to ensure treatment adherence should be made by checking empty blister packs during follow-up visits every month. ${ }^{16}$ All measures should be taken to persuade and encourage patients not to stop treatment despite all its discomforts, as it is the last resort that stands between life and death. Proposed regimen for MDR/RR TB is given in - Table 3. 
WHO has recently revised the grouping of ATDs for use in MDR/RR-TB patients in 2018 into three groups ( $>$ Table 4), based on individual patient data meta-analysis of more than 13,000 patients, depending on their individual efficacy, risk of relapse, treatment failure, and death, ${ }^{17}$ and advised for preferably all oral regimens for treatment of MDR/RR-TB. ${ }^{11,18,19}$ Drugs and their doses according to recent classification and weight bands are given in - Table 5. Recent 2019 WHO consolidated guideline ${ }^{11}$ suggested that MDR/RR-TB patients on longer regimens should have all three group-A agents and at least one group-B agent included to ensure that treatment starts with at least four ATDs likely to be effective and that at least three agents are included for the rest of treatment after bedaquiline is stopped. If only one or two group-A agents are used, both group-B agents are to be included. If the regimen cannot be composed with agents from Groups A and B alone, Group C agents are added to complete the regimen. Kanamycin and capreomycin are not to be included in the treatment of MDR/RR-TB patients on longer regimens. Government of India is in the process of adopting the changes based on this recent WHO guidelines and it has been proposed to use at least five drugs comprising bedaquiline (only for 6 months), levofloxacin, linezolid, clofazimine, and cycloserine in the intensive phase of treatment for 6 to 8 months and four drugs consisting of linezolid, levofloxacin, clofazamine, and cycloserine in the continuation phase of treatment for 12 months.

\section{Treatment of Pre-XDR- and XDR-Tuberculosis}

Proposed regimen for Pre-XDR-TB and XDR-TB ${ }^{14,15}$ with and without newer drugs are given in - Table 3.
U.S. Food and Drug Administration (FDA) recently approved a new all oral regimen (BPal regime) for XDR-TB patients and those MDR-TB patients who cannot tolerate or do not respond to conventional MDR-TB regimen. Regimen comprise of three drugs namely bedaquiline, pretomanid, and linezolid for 6 to 9 months. Nix-TB trial using BPal regimen in XDR-TB showed success rate of $90 \%$ as compared with the present success rate of $30 \%{ }^{20} \mathrm{Nix}-\mathrm{TB}$ study is an important step toward establishing

Table 4 WHO revised grouping of TB medicines 2018

\begin{tabular}{|l|l|}
\hline Group & Medicine \\
\hline $\begin{array}{l}\text { Group A } \\
\text { includes all } \\
\text { three medi- } \\
\text { cines (unless } \\
\text { they cannot } \\
\text { be used) }\end{array}$ & $\begin{array}{l}\text { Levofloxacin OR Moxifloxacin Bedaquiline } \\
\text { Linezolid }\end{array}$ \\
\hline $\begin{array}{l}\text { Group B adds } \\
\text { both medi- } \\
\text { cines (unless } \\
\text { they cannot } \\
\text { be used) }\end{array}$ & Clofazimine \\
\hline $\begin{array}{l}\text { Group C adds } \\
\text { to complete } \\
\text { the regimen } \\
\text { and when } \\
\text { medicines } \\
\text { from groups }\end{array}$ & Ethambutol \\
\cline { 2 - 2 } $\begin{array}{l}\text { A and B can- } \\
\text { not be used }\end{array}$ & Delamanid \\
\cline { 2 - 2 } & Pyrazinamide \\
\cline { 2 - 2 } & Amipenem-cilastatin OR meropenem \\
\cline { 2 - 2 } & Ethionamide OR prothionamide \\
\hline
\end{tabular}

Abbreviations: TB, tuberculosis; WHO, World Health Organization.

Table 5 Drugs and doses used in DR-TB for patients older than 14 years (WHO DR-TB treatment 2018-19)

\begin{tabular}{|c|c|c|c|c|c|c|}
\hline \multirow{2}{*}{$\begin{array}{l}\text { Medicine } \\
\text { Weight groups }(\mathrm{kg})\end{array}$} & \multirow{2}{*}{$\begin{array}{l}\text { Weight-based daily } \\
\text { dose }(\mathrm{mg} / \mathrm{kg})\end{array}$} & \multicolumn{5}{|c|}{ Weight bands for patients older than 14 years } \\
\hline & & $30-35$ & $36-45$ & $46-55$ & $56-70$ & $>70$ \\
\hline Levofloxacin & $10-15$ & 750 & 750 & 1,000 & 1,000 & 1,000 \\
\hline \multirow[t]{2}{*}{ Moxifloxacin } & $7.5-10$ & 400 & 400 & 400 & 400 & 400 \\
\hline & (High dose) 10-15 & $400 / 600$ & 600 & $600 / 800$ & 800 & 800 \\
\hline Bedaquiline & $2-3$ & \multicolumn{5}{|c|}{$\begin{array}{l}400 \mathrm{mg} \text { daily for } 2 \text { weeks } \\
\text { Then } 200 \mathrm{mg} \text { thrice weekly for } 22 \text { weeks }\end{array}$} \\
\hline Linezolid & $10-12$ & 300 & 450 & 600 & 600 & 600 \\
\hline Clofazimine & 1 & 100 & 100 & 100 & 100 & 100 \\
\hline Cycloserine or terizidone & $10-15$ & 500 & 500 & 750 & 750 & 750 \\
\hline Ethambutol & $15-25$ & 800 & 800 & 1200 & 1200 & 1200 \\
\hline Delamanid & 1.5 & $100 \mathrm{BD}$ & $100 \mathrm{BD}$ & $100 \mathrm{BD}$ & $100 \mathrm{BD}$ & $100 \mathrm{BD}$ \\
\hline Pyrazinamide & $20-30$ & 1,000 & 1,500 & 1,500 & 1,500 & 2,000 \\
\hline Imipenem cilastatin & 25 & \multicolumn{5}{|c|}{$2 \mathrm{~g}$ BD (to be used with clavulanic acid) } \\
\hline Meropenem & 20 & \multicolumn{5}{|c|}{$1 \mathrm{~g}$ thrice a day or $2 \mathrm{~g}$ twice a day (to be used with clavulanic acid) } \\
\hline Amikacin & $15-20$ & 500 & 500 & 750 & 750 & 1,000 \\
\hline Streptomycin & $12-18$ & 500 & $600 / 700$ & $800 / 900$ & 900 & 1,000 \\
\hline $\begin{array}{l}\text { Ethionamide or } \\
\text { prothionamide }\end{array}$ & $15-20$ & 500 & 500 & 750 & 750 & 1,000 \\
\hline p-amino salicylic acid & $\begin{array}{l}8-12 \mathrm{~g} / \text { day in } \\
2-3 \text { divided doses }\end{array}$ & \multicolumn{5}{|c|}{$4 \mathrm{~g}$ twice a day } \\
\hline
\end{tabular}


a truly "Universal Regimen" to which there is no preexisting resistance and could therefore treat all type of DR-TB patients, that is, MDR-TB, pre-XDR, and XDR-TB.

\section{Authors' Contributions}

R.P.: chief author and editor; H.S.: compilation of data; N.G.: data collection and editing; M.T.: data collection and tabulation; R.N.: primary framework of data.

\section{Conflict of Interest}

None declared.

\section{References}

1 Prasad R, Gupta N, Multidrug Resistant and Extensively Drug Resistant Tuberculosis: Prevention. In: Prasad R, Gupta N, 1st ed. Clinical Tuberculosis: Diagnosis and Treatment. New Delhi: Jaypee Brothers Medical Publishers; 2015 367-373

2 WHO. Global tuberculosis report 2019. Available at: https:// apps.who.int/iris/bitstream/handle/10665/329368/97892415 65714-eng.pdf?ua=1. Accessed March 5, 2020

3 WHO treatment guidelines for isoniazid-resistant tuberculosis: Supplement to the WHO treatment guidelines for drug-resistant tuberculosis. Available at: https://apps.who. int/iris/bitstream/handle/10665/260494/9789241550079eng.pdf? sequence $=1$. Accessed March 7, 2020

4 Nahid P, Mase SR, Migliori GB, et al. Treatment of drug-resistant tuberculosis. An official ATS/CDC/ERS/IDSA clinical practice guideline. Am J Respir Crit Care Med 2019;200(10):e93-e142

5 Guidelines for the programmatic management of drug-resistant tuberculosis, 2008 update. Available at: https://apps.who. int/iris/bitstream/handle/10665/43965/9789241547581_eng. pdf? sequence=1. Accessed March 16, 2020

6 Guidelines for the programmatic management of drug-resistant tuberculosis, 2011 update. Available at: https://apps.who. int/iris/bitstream/handle/10665/44597/9789241501583_eng. pdf? sequence $=1$. Accessed April 2, 2020

7 WHO treatment guidelines for drug-resistant tuberculosis 2016 update. Available at: https:/apps.who.int/iris/bitstream/ handle/10665/250125/9789241549639-eng.pdf. Accessed March 16, 2020

8 Moodley R, Godec TR; STREAM Trial Team. Short-course treatment for multidrug-resistant tuberculosis: the STREAM trials. Eur Respir Rev 2016;25(139):29-35

9 Nunn AJ, Phillips PP, Meredith SK, et al; STREAM Study Collaborators. A trial of a shorter regimen for rifampin-resistant tuberculosis. N Engl J Med 2019;380(13):1201-1213
10 WHO position statement on the continued use of the shorter MDR-TB regimen following an expedited review of the STREAM Stage 1 preliminary results. Available at: https:// www.who.int/tb/areas-of-work/drug-resistant-tb/treatment/ WHOPositionStatementShorterRegimensSTREAMStage 1. pdf?ua $=1$. Accessed March 23, 2020

11 WHO. WHO Consolidated guidelines on drug-resistant tuberculosis treatment. 2019. Available at: https://apps.who.int/ iris/bitstream/handle/10665/311389/9789241550529-eng. pdf?ua=1. Accessed March 25, 2020

12 Abidi S, Achar J, Assao Neino MM, et al. Standardised shorter regimensversusindividualised longer regimens for rifampin- or multidrug-resistant tuberculosis. Eur Respir J 2020;55(3):1901467

13 International Union Against Tuberculosis and Lung Disease. STREAM stage 2 clinical study first to include Bedaquiline to test shortened treatment regimens. Available at: https:// www.theunion.org/news-centre/photo-stories/stream-video. Accessed April 11, 2019

14 Central TB. Technical and Operational Guidelines for TB Control in India. Available at: https://tbcindia.gov.in/index1. php?sublinkid=4573\&level=2\&lid=3177\&lang=1. Accessed June 17, 2020

15 Revised National tuberculosis Control Programme. Guidelines on programatic management of drug resistant tuberculosis (PMDT) in India. 2017. Available at: https://tbcindia.gov. in/index1.php?lang=1\&level=2\&sublinkid=4780\&lid=3306. Accessed March 28, 2020

16 Singh A, Prasad R, Kushwaha RAS, et al. Treatment outcome of multidrug-resistant tuberculosis with modified DOTS-plus strategy: a 2 years' experience. Lung India 2019;36(5):384-392

17 Ahmad N, Ahuja SD, Akkerman OW, et al; Collaborative Group for the Meta-Analysis of Individual Patient Data in MDR-TB treatment-2017. Treatment correlates of successful outcomes in pulmonary multidrug-resistant tuberculosis: an individual patient data meta-analysis. Lancet 2018;392(10150):821-834

18 World Health Organization. Rapid Communication: Key changes to treatment of multidrug- and rifampicin- resistant tuberculosis. Available at: https://www.who.int/tb/ publications/2019/WHO_RapidCommunicationMDRTB2019. pdf?ua=1. Accessed April 2, 2020

19 WHO. WHO treatment guidelines for multidrug- and rifampicin-resistant tuberculosis (2018 update). 2018. Pre-final text. Available at: https://www.who.int/tb/areas-of-work/drug-resistant-tb/guideline-update2018/en/ April 1, 2020

20 Rapid communication: key changes to treatment of drug-resistant tuberculosis. Available at: https://www.who.int/tb/ publications/2019/WHO_RapidCommunicationMDR_TB2019. pdf?ua=1. Accessed April 2, 2020 